\title{
Hemodialysis is Indicated
}

Jeremy Graham, DO, MA, FACP

Elson S. Floyd College of Medicine, Washington State University, Spokane, WA, USA.

Machines draw close and whittle down the trees

in nature shows before his easy-chair.

The "dozer excavators "slash and burn

a yearly loss the size of New York state"

the narrator laments. The screen displays

the beasts that flee from the advancing steel.

Last year they whittled his left leg away,

a loss that equaled his own baby weight,

when he himself was born in New York State.

He drove such 'dozers on a crew himself,

when days were work instead of nature shows,

before he was confined to easy chairs.

Machines draw closer now to him as well.

They rise above the dome of abdomen

where his life was changed forever.

His beast, his friend, his catheter, peers past

the horizon of his pannus. It seems

to flee a land that's whittled down by steel machines.

Corresponding Author: Jeremy Graham, DO, MA, FACP, Elson S. Floyd College of MedicineWashington State University, Spokane, WA 99202, USA (e-mail:jeremy.graham@wsu.edu).

J Gen Intern Med 31(10): 1263

DOI: $10.1007 / \mathrm{s} 11606-016-3705-3$

(c) Society of General Internal Medicine 2016 